\title{
Statistical Evaluation of Accessibility of Receiving Inclusive Education by Children with Disabilities in Russia
}

\author{
Sadovnikova N.A. \\ Statistics department \\ Plekhanov Russian University of Economics \\ Moscow, Russia \\ Sadovnikova.NA@rea.ru
}

\author{
Bezrukov A.V. \\ Statistics department \\ Plekhanov Russian University of Economics \\ Moscow, Russia \\ Bezrukov.AV@rea.ru
}

\author{
Karmanov M.V. \\ Statistics department \\ Plekhanov Russian University of Economics \\ Moscow, Russia \\ Karmanov.MV@rea.ru
}

\begin{abstract}
The unfavorable tendencies that are defined by the dynamics of children disability in Russia and in the majority of the country's regions, acutely put up the problem of the disabled children self-realization in the row of priority public tasks in the cosial sphere. The solution of this problem is based upon the achievement of high level of inclusion in education. In this context the statistical evaluation of inclusive education accessibility by children with disabilities and children with PWDs is of high practical significance, to which the present article is dedicated. In the article there is characterized the dynamic of children disability in Russia, the analysis of pre-school education reach of children with disabilities is presented, as well as the evaluation of accessibility for children with disabilities of the primary, the basic and the secondary education. The performed research allowed to formulate the conclusions on positive dynamics in the area of accessible education supplication for children with disabilities. It is fundamental for their selfrealization as the key factor of integration into society, selfestablishment as a personality, and the formation of life fulfillment sensation, the increase of vitality, and the development of social contacts by means of removing the sociopsychological barrier with the external environment.
\end{abstract}

Keywords-children with disabilities; inclusive education; selfrealization; education accessibility

\section{INTRODUCTION}

According to the Federal State Statistics Service [1], the total number of people with disabilities as of January 1, 2018 was 12111 thousand people. In general, for the period 20102018. there is a decrease in this indicator by $7.8 \%$. There are 82 people with disabilities per 1000 population, which is $10.8 \%$ less than in 2010 .

Over the studied period, the number of disabled adults is decreasing, while the number of disabled children, on the contrary, increased quite intensively (by 25.4\%), including $2.4 \%$ in the last year. This dynamics leads to an increase in the number of adults with disabilities belonging to the category of disabled people since childhood (by $1.6 \%$ from 1,066 thousand people on January 1, 2017 to 1,083 thousand people on January 1, 2018 -2016). In addition, the structural changes that took place have also led to the increase in proportion of children with disabilities in the total number of disabled people in Russia over 2010 to 2018 from $4.0 \%$ to $5.4 \%$.

TABLE I. DYNAMICS OF DISABLED CHILDREN IN RUSSIA (FOR JANUARY 1 OF THE YEAR)

\begin{tabular}{|c|c|c|c|c|c|}
\hline $\begin{array}{c}\text { Population } \\
\text { disability } \\
\text { characteristics }\end{array}$ & $\mathbf{2 0 1 0}$ & $\mathbf{2 0 1 1}$ & $\mathbf{2 0 1 2}$ & $\mathbf{2 0 1 3}$ & $\mathbf{2 0 1 4}$ \\
\hline $\begin{array}{c}\text { Disabled total, } \\
\text { thousand people }\end{array}$ & 13134 & 13209 & 13189 & 13082 & 12946 \\
\hline $\begin{array}{c}\text { including } \\
\text { disabled } \\
\text { children }\end{array}$ & 519 & 541 & 560 & 568 & 580 \\
\hline $\begin{array}{c}\text { Disabled } \\
\text { children per } \\
\text { 1000 chindrel } \\
\text { under 18 y.o. }\end{array}$ & 20,0 & 20,5 & 21,1 & 20,9 & 20,7 \\
\hline $\begin{array}{c}\text { Proportion of } \\
\text { disabled } \\
\text { children in the } \\
\text { total number of } \\
\text { the disabled, \% }\end{array}$ & 4,0 & 4,1 & 4,2 & 4,3 & 4,5 \\
\hline
\end{tabular}


TABLE I (CONTINUED)

\begin{tabular}{|c|c|c|c|c|}
\hline $\begin{array}{c}\text { Population } \\
\text { disability } \\
\text { characteristics }\end{array}$ & $\mathbf{2 0 1 5}$ & $\mathbf{2 0 1 6}$ & $\mathbf{2 0 1 7}$ & $\mathbf{2 0 1 8}$ \\
\hline $\begin{array}{c}\text { Disabled total, } \\
\text { thousand people }\end{array}$ & 12924 & 12751 & 12259 & 12111 \\
\hline $\begin{array}{c}\text { including disabled } \\
\text { children }\end{array}$ & 605 & 617 & 636 & 651 \\
\hline $\begin{array}{c}\text { Disabled children } \\
\text { per 1000 chindrel } \\
\text { under 18 y.o. }\end{array}$ & 21,3 & 21,8 & 20,6 & 21,7 \\
\hline $\begin{array}{c}\text { Proportion of } \\
\text { disabled children } \\
\text { in the total number } \\
\text { of the disabled, } \%\end{array}$ & 4,7 & 4,8 & 5,2 & 5,4 \\
\hline
\end{tabular}

The increase in the number of children with disabilities and the dynamics of changes in the number of children under the age of 18 both affected the intensity of children disability. At the beginning of 2010, there were 20 disabled children per 1000 children, and by the beginning of 2018 this number increased to 22 per 1000 , correspondingly.

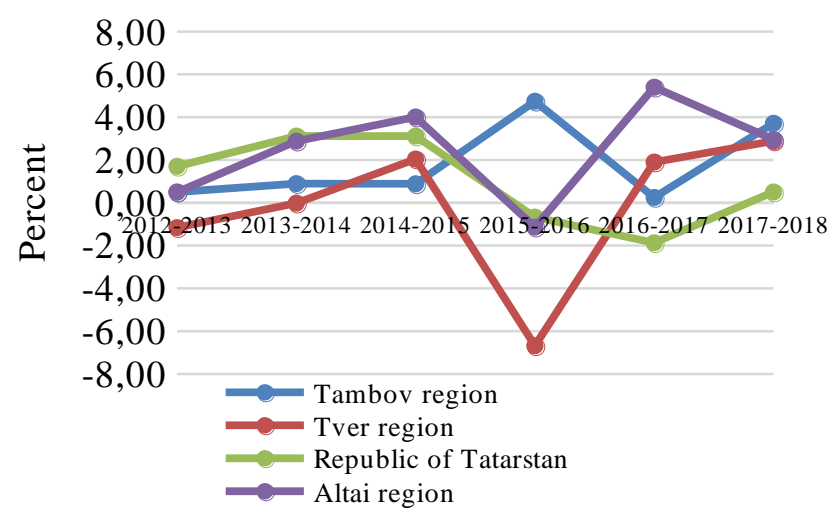

Fig. 1. Growth percents of children with disabilities in certain regions of Russia in 2012 to $2018, \%$

According to Rosstat data, the following changes in the number of children with disabilities that receive social pensions recorded in the Russian Federation regions:

- in the Altai region annual increase is observed in the number of children with disabilities from 8889 people at the beginning of 2012 to 10253 people at the beginning of 2018, in general over the period the growth was $15.34 \%$ (Fig. 1);

- in the Tambov Region, annual increase in the number of children with disabilities is also recorded, from 3,010 people at the beginning of 2012 to 3,353 people at the beginning of 2018, in general over the period the total growth was $11.40 \%$;

- in the Republic of Tatarstan over the period in total, the number of disabled children increased by $5.93 \%$ from 13,987 people at the beginning of 2012 to 14816 people at the beginning of 2018, while in 2015 and 2016 there was some decrease in the indicator;

- in the Tver region, the number of disabled children decreased by 65 children (by $1.35 \%$ ), from 4,808 people at the beginning of 2012 to 4,743 people at the beginning of 2018 , during the period the changes were occurring spasmodically.

In this regard, special attention must be paid to the problem of creating conditions for the socialization of children with disabilities and children with disabilities, the solution of which will expand the opportunities and potential for their successful self-realization.

\section{LITERATURE REVIEW}

Accessibility of education for children with disabilities, being a priority factor for their self-realization, is the subject of a number of scientific projects.

The problems of inclusive education are reflected in the works: Bochkareva T.N., Grigorieva N.V., Evdokimova I.V., Kuchmaeva O.V., Makhova O.A., Podkopaeva A.N., Ryaskova T.N., Sharafieva L.M. and others.

However, despite a significant increase in attention towards the problems of inclusive education, presently there is a lack of works dedicated to comprehensive statistical analysis of the education availability for children with disabilities.

\section{RESEARCH METHODOLOGY}

In order to comprehensively assess the accessibility for children with disabilities of inclusive education quality (as required by Article 24 of the Convention on the Rights of Persons with Disabilities, "Education" [1]), the need for which is dictated primarily by the obligation of the states parties to the Convention to submit reports on the implementation of its requirements and recommendations to the UN Committee on the rights of persons with disabilities, the authors of the study applied the methods of social events and processes statistical analysis, which are based on the use of quantitative and qualitative indicators system to obtain a complete and reliable description of the existing situation.

\section{RESULTS}

In Russia, over the recent years, a large-scale work is carried out in the field of education in order to achieve inclusiveness. The articles of the Convention on the Rights of Persons with Disabilities [2] relating to the rights of children with disabilities are answered by the plan of main activities until 2020, carried out within the framework of the Childhood Decade [3], which provides for a number of activities, including the creation of a modern childhood infrastructure (including the foundation of resource methodological centers and basic professional educational organizations providing support for regional systems of inclusive vocational education for people with disabilities) - Convention, Article 7, 9, 24; on equipping children's art schools with modern equipment (musical instruments, media and film equipment, special stage equipment, technical teaching aids), including equipment taking into account the special needs of children with disabilities - Convention, Article 7, 9, 24, 30; in the field of developing a regulatory framework governing the medical rehabilitation of children, taking into account the results of a pilot project to create a system of comprehensive rehabilitation and habilitation of people with disabilities and children with disabilities as part state of the Russian Federation program 
implementation "Accessible Environment" for 2011 - 2020 [4 ] - Convention Article 7, 25, 26; on the development and implementation of tourist excursion projects for children with disabilities and children with disabilities and inclusive projects in the field of children's tourism - Convention article 7, 30, and such. As part of this plan, in the XII section "Social protection of children with disabilities and children with disabilities and their integration into modern society" a number of measures are provided that are aimed at achieving effective self-realization of children with disabilities, among which it is necessary to highlight:

- improvement of legal regulation of the organization of training for children who master the basic general education programs at home and in medical organizations, which involves certain changes to the organization and implementation of educational activities for basic general educational programs (educational programs of primary, basic, general and secondary general education in terms of definition the procedure for studying at home or in medical organizations);

- monitoring of the compliance with the rights of students with disabilities to receive quality affordable education, the main result of which is the achievement of $100 \%$ coverage of children with disabilities with education at all levels;

- implementation of measures aimed at organizing inclusive general and additional education of children with disabilities, introducing new areas of professional training, retraining and advanced training of teachers to work with students with disabilities and health impairments;

- creation of conditions for ensuring the development and upbringing of children with disabilities, including children with severe and multiple developmental disabilities, in the family, including the development and implementation of training programs for family members with children with disabilities, providing psychological, pedagogical and legal education, selection and use of technical means of rehabilitation, rehabilitation skills, as well as skills in caring for and communicating with children with disabilities;

- creation of conditions for teaching the skills of independent or accompanied living of children with disabilities and young people with disabilities, including those living in stationary social service organizations;

- creation of conditions to increase accessibility for children with disabilities of mass sports, as well as rehabilitation opportunities through adaptive physical education and sports and other activities.

In 2017, measures were taken to ensure the accessibility of priority facilities and services in the priority areas of the life of people with disabilities and other low-mobility groups of people (by the end of 2017, 19802 priority facilities were equipped, which is $57.7 \%$ of the share of priority facilities accessible to people with disabilities and other low-mobility groups of the total number of people), including work carried out to create a versatile barrier-free environment and equipping general education organizations with special equipment (share educational institutions in which a versatile barrier-free environment was created for inclusive education of children with disabilities, in the total number of educational organizations reached 22.4 percent). Measures are taken to provide disabled people with technical rehabilitation equipment.

TABLE II. NUMBER OF PUPILS IN ORGANIZATIONS CARRYING OUT EDUCATIONAL ACTIVITY BY EDUCATIONAL PROGRAMS FOR PRE-SCHOOL EDUCATION, CHILDCARE AND REARING (AT THE END OF YEAR)

\begin{tabular}{|l|l|l|l|l|}
\hline Indicators & $\mathbf{2 0 1 4}$ & $\mathbf{2 0 1 5}$ & $\mathbf{2 0 1 6}$ & $\mathbf{2 0 1 7}$ \\
\hline $\begin{array}{l}\text { Number of pupils in } \\
\text { organizations total, } \\
\text { thousand people }\end{array}$ & 6813,6 & 7151,6 & 7342,9 & 7477,9 \\
\hline $\begin{array}{l}\text { pupils with disabilities } \\
\text { within the total number } \\
\text { of pupils, thousand } \\
\text { people }\end{array}$ & 54,7 & 60,5 & 67,3 & 74,8 \\
\hline $\begin{array}{l}\text { Total number of pupils } \\
\text { growth percent, \% }\end{array}$ & - & 4,96 & 2,67 & 1,84 \\
\hline $\begin{array}{l}\text { Disabled pupils growth } \\
\text { percent, \% }\end{array}$ & - & 10,60 & 11,24 & 11,14 \\
\hline $\begin{array}{l}\text { Proportion of disabled } \\
\text { pupils in the total } \\
\text { number of pupils, \% }\end{array}$ & 0,80 & 0,85 & 0,92 & 1,00 \\
\hline
\end{tabular}

Over the past four years, the total number of pupils and the number of children with disabilities increased annually in organizations that carry out educational activities on educational programs for pre-school education, childcare and rearing. Moreover, a more intensive growth in the number of pupils with disabilities, in contrast to changes in the total number of pupils, led to a significant difference in the total changes over the studied period. The number of students with disabilities at the end of 2014 was 54.7 thousand people, at the end of 2017 - 74.8 thousand people. It is an increase by $36.7 \%$, while the total number of pupils increased only by $9.7 \%$ These large-scale changes led to the fact that the proportion of disabled pupils in the total number of pupils increased from 0.85 to $1 \%[5,6,7,8]$.

In the consolidated annual report on the implementation and evaluation of the Russian Federation state programs effectiveness in 2017 [5], it was noted that the proportion of children with disabilities from 1.5 to 7 years of age enrolled in preschool education, of the total number of children with disabilities of this age amounted to $85.0 \%$ (planned value -85.0 percent). The proportion of children with disabilities who created the conditions for obtaining high-quality primary general, basic general, secondary general education in the total number of school-aged children with disabilities is $97.0 \%$ (planned value - 97.0 percent) $[9,10,11]$.

According to sample observation of quality and accessibility of services in the fields of education, health and social services and employment promotion [6] conducted by Rosstat, the disabled children who studied at a general educational organization in the 2016/2017 academic year are generally satisfied with the work of general educational organizations (according to assessment by parents), including: fully satisfied $-14.5 \%$ of the total respondents number, rather satisfied $-60.1 \%$ of the respondents. $53.7 \%$ of respondents were fully satisfied with the organization of the educational process (class filling, shift, number of training days, homework load, provision of teaching aids, variety and quality of training equipment). $59.8 \%$ of respondents are fully satisfied with the 
quality of training (regularity of classes according to the schedule, professional training of teachers, a variety of additional classes). The percentage of fully satisfied with other characteristics of the work of educational institutions: $67.2 \%$ the quality of educational work; $60.2 \%$ - the comfort of staying in a general educational organization (cleanliness of the premises, serviceability of furniture, air temperature, hygiene amenities); $59.7 \%$ - the safety of staying in the building of a general educational organization and on its territory (condition of the building, improvement and protection of the territory); $56.7 \%$ - by the regularity and procedure for organizing extracurricular activities; $56.2 \%$ - by the organization of medical control and medical care; $53.8 \%$ - by the quality of food $[12,13]$.

Today, children with disabilities are studying in general educational organizations: in the Tambov Region - 1825 children with disabilities; in the Tver region - 2483 disabled children; in the Altai Territory - 4954 people; in the Republic of Tatarstan - 7954 disabled children. Of these, 70 - 80\% study in general educational organizations, the remaining part of them study in individual general educational organizations that implement adapted educational programs.

A significant amount of effort is being performed on the regional level in Russia that is meant to create conditions and innovative mechanisms for the development of inclusive education $[14,15]$.

\section{DISCUSSION}

It is presently possible to state that a barrier-free environment for children with disabilities to receive education at any level is established. However, based on the data of the "Population Living Conditions Comprehensive Observation" conducted by Rosstat [7], despite the fact that for the period from 2014 to 2016 attendance at educational institutions by children with disabilities aged 9-15 years increased from $69.0 \%$ to $72.2 \%$, the proportion of students studying at home with attachment to a particular educational institution increased from $16.7 \%$ in 2014 to $18.0 \%$ in 2016, and, judging by the answers of parents, the proportion of children with disabilities who do not attend a general education institution for one reason or another decreased, including the reason why children with disabilities are not subject to education for health reasons (for this reason recorded decline from $12.3 \%$ in 2014 to $8 \%$ in 2016), today we are faced with the problem of parents reluctance in vocational education for their disabled children. The opinion of children with disabilities parents who are currently receiving some form of general education on the need for further education of children with disabilities is equally divergent. The people who are pre-determined to provide their children with primary or secondary vocational education constitute $34.2 \%$ of the respondents; with higher vocational education $-8.6 \%$. A very high percentage is of those who are not focused on continuing their child's education in the vocational education system, which is $40.4 \%$ of respondents. $16.8 \%$ of children with disabilities parents found the question difficult to answer.

The lack of vocational education for children with disabilities may play a rather fatal role for them in the future in the form of exclusion from society. In this regard, a number of measures must be developed and adopted today that are aimed at developing pre-vocational training, including vocational guidance for children with disabilities to choose a vocational educational institution and a future profession, as well as obtaining primary skills and labor skills. These measures should contribute not only to the professional orientation of children with disabilities, but also to form psychological attitudes such as unwillingness to be a burden for the family, to have an additional source of income and to be included in society.

\section{CONCLUSIONS}

Based on the performed analysis, it is necessary to conclude that it is presently extremely vital to develop inclusive education on a larger scale, which will primarily reduce the segregation of children with disabilities by a significant amount, as well as provide a beneficial effect on their social adaptation and self-realization.

While describing the current state in the area of inclusion of education, it is necessary to note the positive dynamics, which evide the increase in the availability of preschool, primary general, basic general and secondary general education for disabled children. The number of children with disabilities and PWD children among students in recent years has increased. This growth is determined by state policy to improve the situation of children in the Russian Federation, including measures aimed at developing an inclusive education system.

\section{References}

[1] Federal State Statistics Service. Disabled people. [Electronic resource]. Access mode: http://www.gks.ru/wps/wcm/connect/rosstat_main/rosstat/ru/statistics/po pulation/disabilities/\# (accessed 08.16.2019).

[2] Convention on the Rights of Persons with Disabilities. [Electronic resource]. - Access mode: https://www.un.org/en/documents/decl_conv/conventions/disability.sht $\mathrm{ml}$ (accessed 08/16/2019).

[3] Decree of the Government of the Russian Federation of 07.07.2018 N 1375-r (as amended on 08.08.2019) "On approval of the plan of main activities until 2020, carried out as part of the Decade of Childhood" [Electronic resource]. - Access mode: http://www.consultant.ru/document/cons_doc_LAW_301904/119d657df cd17a434f287c95d3568b3b0e484daa/ (accessed 08.17.2019).

[4] Decree of the Government of the Russian Federation of December 1, 2015 N 1297 (as amended on December 27, 2018) "On the approval of the state program of the Russian Federation" Accessible environment "for 2011 2020". [Electronic resource]. - Access mode: http://www.consultant.ru/document/cons_doc_LAW_189921/ (accessed 08.17.2019).

[5] Portal of state programs of the Russian Federation. Summary reporting. [Electronic resource]. - Access mode: https://programs.gov.ru/Portal/analytics/quarterReportToGovernment (accessed 08.21.2019).

[6] Selective monitoring of the quality and accessibility of services in the fields of education, healthcare and social services, promoting employment 2017. [Electronic resource]. - Access mode: http://www.gks.ru/free_doc/new_site/quality17/index.html (accessed 08.21.2019).

[7] Federal State Statistics Service. Disabled people. [Electronic resource]. Access mode: http://www.gks.ru/wps/wcm/connect/rosstat_main/rosstat/ru/statistics/po pulation/disabilities/\# (date of access 08.16.2019)

[8] Federal Law "On Education in the Russian Federation" dated December 29, 2012 No. 273-FZ (latest revision). [Electronic resource]. - Access mode: http://www.consultant.ru/document/cons_doc_LAW_140174/ (accessed: 08/20/2019). 
[Electronic resource]. https://programs.gov.ru/Portal/analytics/quarterReportToGovernment (accessed 08/18/2019).

[13] Titov S.V., Kuznetsova Z.M. Rise of physical fitness level in special student's medical groups by means of athletic gymnastics. Pedagogicopshychological and medico-biological problems of physical culture and sport. 2009, vol. 4(4), pp. 125-130.

[14] Alexsandr S. Kuznetsov. Russian Professor's meeting. Russian Journal of Physical Education and Sport. 2019, 14(1), pp. 17-22. DOI: 10.14526/2070-4798-2019-14-1-18-24

[15] Ryaskova T.N. Implementation of federal state standards for the organization of inclusive education for children with disabilities and children with disabilities (guidelines) // Inclusion in education. - 2018 .-No. 3 (9). - pp. 100-108

[11] The Federal Register of Disabled Persons. Statistics. [Electronic resource]. - Access mode: https://sfri.ru/stat/ (accessed date: 08/16/2019).

[12] Portal of state programs of the Russian Federation. Summary reporting. 